\title{
Testosterone-dependent variations in plasma and intrapituitary corticosteroid binding globulin and stress hypothalamic-pituitary-adrenal activity in the male rat
}

\author{
Victor Viau and Michael J Meaney ${ }^{1}$ \\ Department of Anatomy and Cell Biology, University of British Columbia, Vancouver, Canada \\ ${ }^{1}$ Departments of Psychiatry and Neurology and Neurosurgery, McGill University, Montreal, Canada \\ (Requests for offprints should be addressed to V Viau, Department of Anatomy and Cell Biology, University of British Columbia, 2177 Westbrook Mall, \\ Vancouver BC, Canada V6T1Z3; Email: viau@interchange.ubc.ca)
}

\begin{abstract}
Hypothalamic-pituitary-adrenal (HPA) activity is governed by glucocorticoid negative feedback and the magnitude of this signal is determined, in part, by variations in plasma corticosteroid-binding globulin (CBG) capacity. Here, in gonadectomized male rats we examine the extent to which different testosterone replacement levels impact on CBG and HPA function. Compared with gonadectomized rats with low testosterone replacement $(\sim 2 \mathrm{ng} /$ $\mathrm{ml})$, plasma adrenocorticotropin and $\beta$-endorphin $/ \beta$ lipotropin responses to restraint stress were reduced in gonadectomized rats with high testosterone replacement ( $5 \mathrm{ng} / \mathrm{ml}$ ). Plasma CBG levels also varied negatively as a function of testosterone concentration. Moreover, glucocorticoid receptor binding in the liver was elevated by higher testosterone replacement, suggesting that testosterone acts to enhance glucocorticoid suppression of CBG synthesis. Since pituitary intracellular CBG (or transcortin)
\end{abstract}

is derived from plasma, this prompted us to examine whether transcortin binding was similarly responsive to different testosterone replacement levels. Transcortin binding was lower in gonadectomized rats with high plasma testosterone replacement $(\sim 7 \mathrm{ng} / \mathrm{ml})$ than in gonadectomized rats with low testosterone replacement $(\sim 2 \mathrm{ng} / \mathrm{ml})$. This testosterone-dependent decrease in pituitary transcortin was associated, in vitro, with an enhanced nuclear uptake of corticosterone. These findings indicate that the inhibitory effects of testosterone on corticotrope responses to stress may be linked to decrements in plasma and intrapituitary CBG. This could permit greater access of corticosterone to its receptors and enhance glucocorticoid feedback regulation of ACTH release and/or proopiomelanocortin processing.

Journal of Endocrinology (2004) 181, 223-231

\section{Introduction}

Hypothalamic-pituitary-adrenal (HPA) activity is regulated by a negative feedback process in which circulating glucocorticoids act at various target sites in the brain and pituitary to limit the secretion of adrenocorticotropin $(\mathrm{ACTH})$. Corticosterone (the principal glucocorticoid in the rat) circulates either bound to its specific plasma binder corticosteroid-binding globulin (CBG) or in the free form. The amount of corticosterone that is taken up by target tissue is approximated by the non-CBG bound (free+albumin) fraction of total circulating steroid (Siiteri et al. 1982, Pardridge et al. 1981). Thus, differences in circulating CBG levels determine the magnitude of the glucocorticoid negative-feedback signal (Henning 1978, Walker et al. 1986, 1990). For example, CBG levels in the neonate are markedly reduced (Viau et al. 1996), resulting in a higher proportion of total circulating corticosterone in the free state which contributes to reduced ACTH responses to stress (Walker et al. 1986, 1990). Circulating CBG levels are approximately twofold higher in adult female rats compared with males (Gala \& Westphal 1965, Keller et al. 1966). This sex difference is attributed to androgenic effects in males, as treatment with testosterone or dihydrotestosterone (DHT), the reduced nonaromatizable derivative of testosterone, reverses the stimulatory effects of gonadectomy on plasma CBG (Gala \& Westphal 1965, Keller et al. 1966, McCormick et al. 2002), while estrogen elevates plasma CBG in male rodents (McCormick et al. 2002; but see Kurabekova et al. 1988).

Within the brain and pituitary, glucocorticoid negative feedback inhibition of ACTH release is mediated by two corticosteroid receptor subtypes, including the mineralocorticoid and glucocorticoid receptors (reviewed in Dallman et al. 1987, Jacobson \& Sapolsky 1991; see also Reul \& de Kloet 1985). In addition to these receptors, numerous studies have identified the presence of intracellular CBG (or transcortin) in the anterior pituitary 
corticotrope (de Kloet \& McEwen 1976, Koch et al. 1976). Pituitary transcortin binds corticosterone with high affinity, but unlike the corticosteroid receptors, does not translocate into the cell nucleus, effectively limiting the nuclear corticosterone signal (Sakly \& Koch 1981, 1983). Decreased levels of transcortin in the pituitary have been associated, in vitro, with an enhanced nuclear accumulation of corticosterone and feedback inhibition of ACTH release (Sakly \& Koch 1981, Walker et al. 1986). This phenomenon is consistent with the exclusive distribution of CBG within corticotrope cells of the anterior pituitary (PerrotApplanat et al. 1984). Thus, alterations in glucocorticoid feedback efficacy at the level of the corticotrope can be determined by the binding capacity of transcortin, independent of the corticosteroid receptors.

Plasma ACTH responses to stress are typically higher in female than in male rats (Le Mevel et al. 1978). Since both plasma and pituitary CBG levels are lower in males, the sex difference in ACTH release during stress may possibly reflect a greater glucocorticoid feedback signal in the blood and pituitary in males. The present study extends our earlier findings showing that ACTH responses to stress vary inversely as a function of individual differences in circulating testosterone levels in gonadal-intact male rats, and in a dose-related inhibitory manner in testosteronereplaced gonadectomized male rats (Viau \& Meaney 1996). Here, using gonadectomized rats we revisit the dose-related effects of testosterone on plasma and intrapituitary CBG, determining, in turn, how these effects on CBG could impact on stress-related HPA function.

\section{Materials and Methods}

\section{Animals}

Long-Evans hooded rats (Charles River Canada, St Constant, Quebec, Canada) were used, weighing approximately $300 \mathrm{~g}$ at testing. Rats were housed with food and drinking water available ad libitum. All rats were bilaterally gonadectomized (GDX) and immediately implanted with either one, two or three subcutaneous Silastic capsules (Dow Corning, Midland, MI, USA; each $25 \mathrm{~mm}$ length, $1.57 \mathrm{~mm}$ ID, $3.18 \mathrm{~mm}$ OD) filled with crystalline testosterone; the capsules were designed to provide circulating testosterone levels over the normal physiological range in a $300 \mathrm{~g}$ rat (Smith et al. 1977). Plasma and tissue samples were obtained two weeks following castration and implantation of testosterone-filled capsules. Room temperature was maintained at $20-22{ }^{\circ} \mathrm{C}$ with a $12 \mathrm{~h}$ light: $12 \mathrm{~h}$ darkness schedule (lights on from 0800-2000 h). Hormone measures during restraint were obtained from blood samples collected from an indwelling right jugular vein silastic cannula (Dow Corning; 0.025 ID, 0.047 OD) exiting from the back of the neck, and replaced with an equal volume of normal saline $(0 \cdot 9 \%)$ via the same route. Jugular catheterizations were performed using the inhala- tion anesthetic Metofane (methoxyflurane; Pitman-Moore Inc., Washington Crossing, NJ, USA) four days prior to testing.

\section{Restraint stress experiments}

In all cases restraint stress was performed between 1200 and $1500 \mathrm{~h}$. Prestress blood samples were taken from rats within $30 \mathrm{~s}$ of removal from the cage. Rats were then immediately placed in restrainers for a period of $10 \mathrm{~min}$, after which blood was sampled at $0,10,20,30$, and $60 \mathrm{~min}$ post stress. Blood samples $(300 \mu \mathrm{l})$ were collected in iced tubes containing $10 \mu \mathrm{l}$ EDTA and Trasylol (aprotinin; Miles Laboratories, Mississauga, Ontario, Canada), centrifuged at $3000 \boldsymbol{g}$ for $10 \mathrm{~min}$, and stored at $-80^{\circ} \mathrm{C}$ until assayed. All protocols were approved by the Animal Care Committee of McGill University and the University of British Columbia.

\section{Plasma CBG assay}

Plasma CBG was measured by a method similar to that of Martin et al. (1977). Endogenous steroids were removed from plasma samples by passing the plasma through Sephadex LH-20 (Pharmacia Fine Chemicals, Dorval, Quebec, Canada) columns $(7 \times 1 \mathrm{~cm})$ and diluting the eluents 1:50 (v/v) in $30 \mathrm{mM}$ Tris, $1 \mathrm{mM}$ EDTA, $10 \mathrm{mM}$ sodium molybdate, $10 \% \mathrm{v} / \mathrm{v}$ glycerol, and $1 \mathrm{mM}$ dithiothreitol (TEDGM; pH adjusted to 7·4). Diluted plasma $(225 \mu \mathrm{l})$ was incubated in the presence of $80 \mathrm{nM}\left[{ }^{3} \mathrm{H}\right]$ corticosterone overnight at $0{ }^{\circ} \mathrm{C}$ with or without a 200 -fold excess of unlabeled corticosterone (total and non-specific binding respectively). A fraction of the diluted plasma was assayed for protein content. Following the incubation, separation of bound from free ligand was performed using Sephadex LH-20 columns equilibrated with TEDGM. The incubates $(100 \mu \mathrm{l})$ were washed onto the columns with $100 \mu \mathrm{l}$ TEDGM. The columns were then eluted $30 \mathrm{~min}$ later with $500 \mu \mathrm{l}$ TEGM, and collected into mini-vials which were then filled with $5 \mathrm{ml}$ Liquiscent (National Diagnostics, Somerville, NJ, USA), and counted in a Packard scintillation counter. Plasma CBG values are expressed as $\mathrm{nM}$ concentrations.

\section{Intrapituitary CBG (transcortin) assay}

Transcortin binding sites were determined as previously described (Meaney et al. 1985). Briefly, whole pituitaries were homogenized in TEDGM and then centrifuged for $60 \mathrm{~min}$ at $105000 \mathrm{~g}$. Protein concentrations of the supernatants were determined using the method of Bradford (1976). The soluble fraction was then incubated at $0{ }^{\circ} \mathrm{C}$ for $22 \mathrm{~h}$ with a saturating concentration of $\left[{ }^{3} \mathrm{H}\right]$ corticosterone $(20 \mathrm{nM})$ and a $500-$ fold excess of unlabeled dexamethasone (DEX; to preclude binding to glucocorticoid receptor sites) with or without a 200 -fold excess of unlabeled 
corticosterone. Incubates were chromatographed on Sephadex LH-20 as described for the plasma CBG assay. Results are expressed as fmol/mg protein.

\section{Hepatic corticosteroid receptors}

Tissue was obtained from a separate group of testosteronereplaced gonadectomized rats killed by decapitation $16 \mathrm{~h}$ following adrenalectomy to allow for adequate clearance of corticosterone. Liver fragments were quickly dissected and stored at $-80{ }^{\circ} \mathrm{C}$ until assayed. The tissue was homogenized in TEDGM and centrifuged for $60 \mathrm{~min}$ at $105000 \mathrm{~g}$. Protein concentrations of the supernatants were determined using the method of Bradford (1976). Single point glucocorticoid receptor binding assays were performed by incubating $225 \mu \mathrm{l}$ aliquots of the soluble fraction with $150 \mu \mathrm{l}$ of a saturating $10 \mathrm{nM}$ concentration of $\left.{ }^{3} \mathrm{H}\right] \mathrm{DEX} \quad(88.7 \mu \mathrm{Ci} / \mathrm{mmol}$, New England Nuclear, Boston, MA, USA) with or without a 200-fold excess of the glucocorticoid receptor agonist RU28362. RU28362 binds selectively to the glucocorticoid receptor, showing very little affinity for the mineralocorticoid receptor (Coirini et al. 1985, Reul \& de Kloet 1985). Mineralocorticoid receptor determinations were performed by incubating the soluble fractions with $150 \mu$ l of a saturating $7 \mathrm{nM}$ concentration of $\left[{ }^{3} \mathrm{H}\right]$ corticosterone $(88 \cdot 0 \mu \mathrm{Ci} /$ mmol, New England Nuclear) with a 25-fold excess of RU28362, with or without a 200-fold excess of aldosterone. Following a $24 \mathrm{~h}$ and $48 \mathrm{~h}$ incubation at $0{ }^{\circ} \mathrm{C}$ for mineralocorticoid and glucocorticoid receptors respectively, separation of bound from free ligand was performed on Sephadex LH-20 columns, after which the bound fraction was counted, as discussed above. The specific binding is expressed as $\mathrm{fmol} / \mathrm{mg}$ protein.

\section{Anterior pituitary $\left.{ }^{3} H\right]$ corticosterone nuclear uptake}

Pituitaries were obtained from the same groups of testosterone-replaced gonadectomized rats used in the hepatic corticosteroid receptor study, likewise killed by decapitation $16 \mathrm{~h}$ following adrenalectomy. As previously described (Koch et al. 1974), anterior pituitaries were homogenized in buffer containing $0.01 \mathrm{M} \mathrm{MgCl}_{2}$, $0.025 \mathrm{M} \mathrm{KCl}$ and $0.002 \mathrm{M}$ dithiothreitol (pH 7.4). Protein concentrations of the homogenates were determined using the method of Bradford (1976). Homogenates were then incubated at $25{ }^{\circ} \mathrm{C}$ in the presence of either 10 or $100 \mathrm{nM}$ $\left[{ }^{3} \mathrm{H}\right]$ corticosterone. Non-specific uptake was determined in parallel incubations containing a 200-fold excess of unlabeled corticosterone. The homogenates were then centrifuged at $600 \boldsymbol{g}$ for $10 \mathrm{~min}$ and the resulting pellet was then resuspended and centrifuged $(600 \mathrm{~g})$ in homogenate buffer supplemented with $0 \cdot 2 \% \mathrm{v} / \mathrm{v}$ Triton X-100 and $0.25 \mathrm{M}$ sucrose. The crude nuclear fraction was then obtained following three successive resuspensions and centrifugations in homogenate buffer supplemented with
0.32 M sucrose. Radioligand was then extracted from the nuclear pellet with $1 \mathrm{ml}$ ethanol and counted. Specific nuclear uptake is expressed as $\mathrm{fmol} / \mathrm{mg}$ protein.

\section{Radioimmunoassays}

Plasma $(10 \mu \mathrm{l})$ corticosterone was measured by RIA using a highly specific corticosterone antiserum (B3-163, Endocrine Sciences, Tarzana, CA, USA) and $\left[{ }^{3} \mathrm{H}\right]$ corticosterone (101 Ci/mmol, New England Nuclear) as tracer, as previously described (Viau et al. 1993, 1996). Briefly, $10 \mu \mathrm{l}$ plasma samples were extracted in $1 \mathrm{ml}$ ice-chilled ethanol, and then centrifuged for $10 \mathrm{~min}$ at $3000 \mathrm{~g}$. Duplicate $100 \mu \mathrm{l}$ aliquots of each supernatant were vacuum dried, and then reconstituted and incubated overnight in $100 \mu \mathrm{l}$ phosphate-buffered saline containing corticosterone antisera (diluted $40 \mu \mathrm{l} / \mathrm{ml}$ PBS) and $100 \mu \mathrm{l}$ $\left[{ }^{3} \mathrm{H}\right]$ corticosterone $\left(15 \times 10^{3}\right.$ c.p.m. per $\left.100 \mu \mathrm{l} \mathrm{PBS}\right)$ at $4{ }^{\circ} \mathrm{C}$. After $24 \mathrm{~h}$, separation of bound from free corticosterone was achieved by incubating the samples in PBSdextran-coated charcoal for $15 \mathrm{~min}$, then centrifuged for $10 \mathrm{~min}$ at $3000 \mathrm{~g}$. Finally, $1 \mathrm{ml}$ of the supernatant (free fraction) was counted in $5 \mathrm{ml}$ scintillation cocktail. The antiserum cross-reacts slightly with desoxycorticosterone $(\sim 4 \%)$, but not with aldosterone, cortisol or progesterone $(<1 \%)$. The detection limit of the assay was $10 \mathrm{ng} / \mathrm{ml}$. The intra- and interassay coefficients of variation were 8.8 and $10 \cdot 4 \%$ respectively.

The free or non-CBG-bound fraction of total corticosterone was calculated from the total molar concentrations of corticosterone and CBG using a variation of a mass action equation (Plymate et al. 1987), and employing the dissociation constant of corticosterone and CBG $\left(K_{\mathrm{d}} \sim\right.$ $13 \mathrm{nM}$ ). This calculation has been validated with direct measures of free steroid, as seen by the relationship between free, total, and sex hormone-binding globulinbound testosterone concentrations (see Plymate et al. 1989). Further, individual differences in plasma CBG levels, as detected by the plasma CBG binding method used in the present study, are met by parallel differences in free corticosterone levels measured directly (Viau et al. 1996, Tannenbaum et al. 1997).

Plasma $(25 \mu \mathrm{l})$ testosterone was measured using the RIA kit of ICN-Biomedicals (Carson, CA, USA) with $\left[{ }^{125} \mathrm{I}\right]$ testosterone as tracer. The testosterone antibody (solid phase) cross-reacts slightly with $5 \alpha$-dihydrotestosterone (7·8\%), $5 \alpha$-androstane-3 $\beta, 17 \beta$-diol $(2 \cdot 2 \%)$ and 11 -oxotestosterone $(2 \%)$, but does not cross-react with progesterone, estrogen, or with the glucocorticoids (all $<0.01 \%)$. The detection limit of the assay was $0.6 \mathrm{ng} / \mathrm{ml}$. The intra- and interassay coefficients of variation were 3.5 and $10 \cdot 0 \%$ respectively.

Plasma $(25 \mu \mathrm{l})$ ACTH concentrations were measured by RIA as previously described (Viau et al. 1993). Briefly, unextracted plasma was incubated overnight at $4{ }^{\circ} \mathrm{C}$ with a specific ACTH antiserum at a final dilution of 
1:120 000 (IgG Corp., Nashville, TN, USA) and $\left[{ }^{125} \mathrm{I}\right] \mathrm{ACTH}$ (Incstar, Stillwater, MN, USA) as tracer (5000 c.p.m./tube). The ACTH antibody cross-reacts 100\% with ACTH1-39, ACTH1-18 and ACTH1-24, but not with ACTH1-16, $\beta$-endorphin ( $\beta$-END), $\alpha$ - and $\beta$-melanocyte stimulating hormone (MSH), and $\alpha$ - and $\beta$-lipotropin $(\mathrm{LPH}) \quad(<1 \%)$. After $48 \mathrm{~h}$ of further incubation, precipitation serum (Antibodies Inc., Davis, CA, USA) was added and bound peptide was obtained by centrifugation at $5000 \mathrm{~g}$ for $45 \mathrm{~min}$. The detection limit of the assay was $10 \mathrm{pg} / \mathrm{ml}$. The intra- and interassay coefficients of variation were 7.5 and $12.0 \%$ respectively.

Plasma $\beta$-END/ $\beta$-LPH was determined by RIA from $25 \mu \mathrm{l}$ unextracted plasma as previously described (Iny et al. 1987) using an antiserum specific for the C-terminus of $\beta$-endorphin1-31 ( $\beta$-END) at a final dilution of 1:30 000 and $\left[{ }^{125} \mathrm{I}\right] \beta-E N D 1-31$ as tracer (12 000 c.p.m./tube). The $\beta$-END antibody cross-reacts $\sim 100 \%$ with $\beta$-lipotropin $(\beta-\mathrm{LPH})$ and $\alpha-\mathrm{N}$-acetylated $\beta-\mathrm{END}, \quad 70 \%$ with $\beta$-END1-27, but not with ACTH, $\alpha-\mathrm{MSH}, \beta-\mathrm{MSH}$, nor with $\beta-\mathrm{LPH}$ fragments $61-65,62-67$ and $80-84$. The detection limit of the assay was $10 \mathrm{pg} / \mathrm{ml}$. The intra- and interassay coefficients of variation were 8.6 and $9 \cdot 8 \%$ respectively. Plasma ACTH and $\beta-\mathrm{END} / \beta-\mathrm{LPH}$ values were expressed in $\mathrm{pM}$ concentrations, permitting direct molar comparisons in their release profiles.

Integrated ACTH and $\beta$-END/ $\beta-\mathrm{LPH}(\mathrm{pM} / \mathrm{min})$ responses were derived using the area under the curve (AUC) trapezoidal method (Tallarida \& Murray 1981), in which the area under each temporal segment was totalled and averaged over the entire 70 min sampling period. Stress peak integral ACTH and $\beta$-END/ $\beta-\mathrm{LPH}$ levels were determined by subtracting peak from basal plasma hormone values (see Table 1). Finally, the ratio of $\beta$-END/ $\beta$-LPH:ACTH was used to provide an index of the relative release profile of these peptides.

\section{Statistical analysis}

Data were analyzed using analysis of variance (ANOVA). Tukey post-hoc tests were used, where appropriate, to explore the source of significant effects. Statistical and regression analyses were performed using Statview (Power PC version 5·01, Cary, NC, USA).

\section{Results}

\section{Plasma testosterone replacement}

Plasma testosterone replacement levels in GDX male rats approximated the physiological range seen in gonadal intact male rats. The variation in plasma testosterone concentrations produced was ample enough to demonstrate the dose-related nature by which testosterone nor-

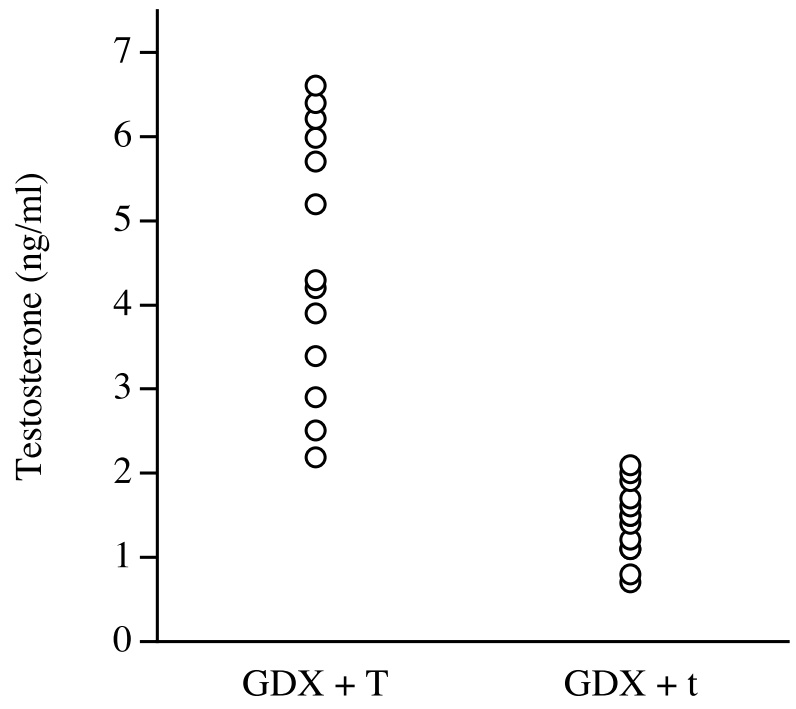

Figure 1 Individual plasma testosterone levels in GDX male rats with subcutaneous testosterone implants. Ranked according to plasma steroid concentrations, the median testosterone value was $2.6 \mathrm{ng} / \mathrm{ml}$. Rats with testosterone levels greater or less than this value were grouped as GDX high testosterone (T) or GDX low testosterone (t) respectively ( $n=13$ rats per group).

mally operates on HPA function (Fig. 1). To illustrate this feature, rats were grouped based on their individual testosterone levels, either above or below the median testosterone level of $2 \cdot 7 \mathrm{ng} / \mathrm{ml}$. Thus, as groups, the mean testosterone concentrations were $5.1 \pm 0.6 \mathrm{ng} / \mathrm{ml}$ $(\mathrm{GDX}+$ high $\mathrm{T})$ and $1.7 \pm 0.3 \mathrm{ng} / \mathrm{ml}(\mathrm{GDX}+$ low $\mathrm{t})$. The data presented in Figs $2-4$ and in Table 1 were determined from these testosterone-replaced GDX rats. The final two studies examining hepatic corticosteroid receptors and pituitary nuclear uptake (Figs 5 and 6 respectively) were derived from separate groups of testosterone-replaced GDX rats, in which the mean plasma testosterone concentrations were $7 \cdot 6 \pm 0.7 \mathrm{ng} / \mathrm{ml}(\mathrm{GDX}+$ high $\mathrm{T})$ and $2 \cdot 5 \pm 0 \cdot 5 \mathrm{ng} / \mathrm{ml}(\mathrm{GDX}+$ low $\mathrm{t})$.

\section{Plasma ACTH and $\beta$-END/ $\beta-L P H$ responses to restraint}

Relative to GDX rats replaced with low testosterone levels, GDX rats with higher plasma testosterone concentrations showed reduced ACTH and $\beta-E N D / \beta-\mathrm{LPH}$ responses over the entire testing period (Fig. 2). This was attributed to testosterone-dependent differences in peak ACTH and $\beta-E N D / \beta-$ LPH levels, achieved at the end of restraint exposure (see Stress peak integral, Table 1). No significant differences were found in pre-stress levels of $\mathrm{ACTH}$ and $\beta-\mathrm{END} / \beta-\mathrm{LPH}$. Independent of testosterone, the $\beta$-END/ $\beta$-LPH:ACTH ratio was highest under basal conditions, and nearly 1:1 during restraint-stress 


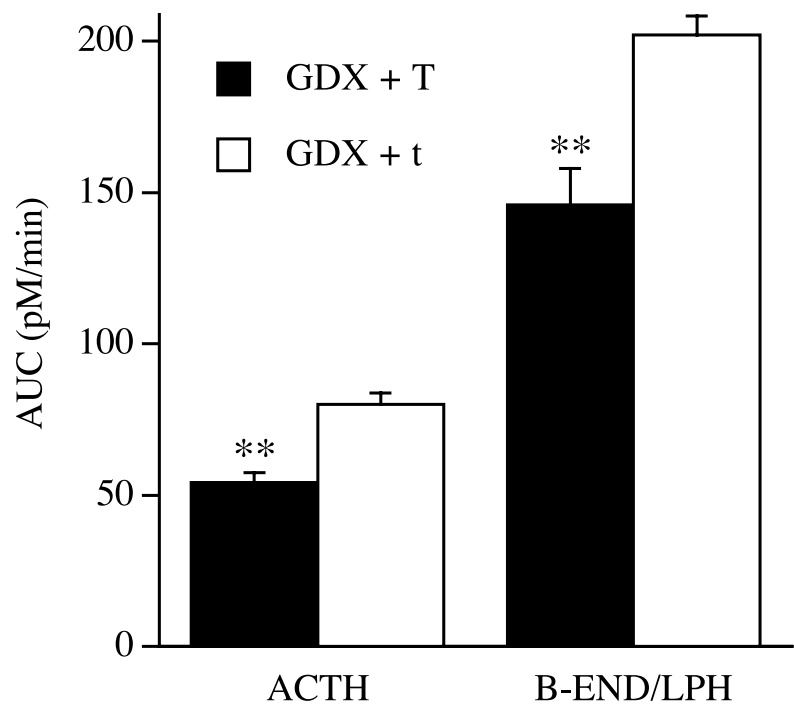

Figure 2 Mean ( \pm S.E.M.) integrated plasma ACTH and $\beta$-END/ $\beta$-LPH responses to 10 min of restraint stress in GDX+high T and in GDX+low t replaced rats $\left(n=13\right.$ rats per group). ${ }^{* *} P<0 \cdot 01$ compared with GDX rats with low testosterone replacement.

(see Ratio, Table 1). This is consistent with previous studies using antisera identical to our own, showing that circulating endorphins dominate over ACTH under basal conditions, approaching uniformity under stress conditions (De Souza \& Van Loon, 1985, Van Loon \& De Souza 1987). The latter is in line with the fact that $\beta-\mathrm{LPH}$, originating from anterior pituitary corticotropes, is the principal endorphin secreted during acute stress exposure. The $\beta$-END/ $\beta$-LPH:ACTH ratio varied as a function of testosterone replacement, however, being significantly lower in GDX+high testosterone replaced rats than in GDX+low testosterone replaced rats (see Stress peak integral ratio, Table 1).

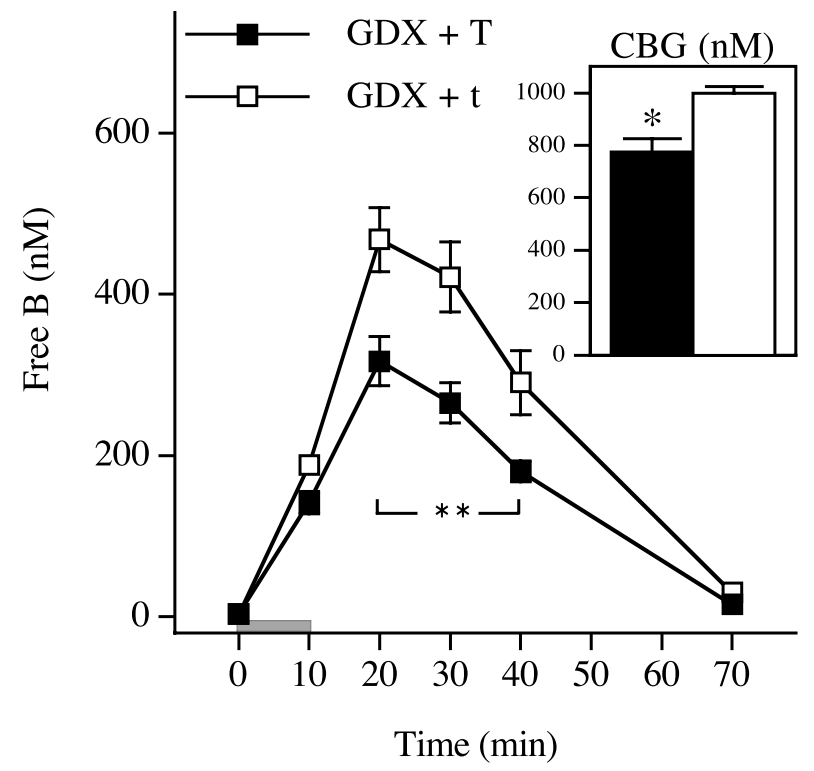

Figure 3 Mean ( \pm S.E.M.) free plasma corticosterone (B) responses to 10 min of restraint stress in GDX+high T and in GDX+low t replaced rats. Inset: mean ( \pm S.E.M.) plasma CBG levels $(n=13$ rats per group). ${ }^{*} P<0.05,{ }^{*} P<0.01$ compared with GDX rats with low testosterone replacement.

Plasma CBG and free corticosterone responses to restraint stress

Plasma CBG levels were reduced in GDX rats replaced with higher testosterone replacement levels (see Fig. 3 inset). Despite this difference in plasma CBG, and owing to a larger disparity in total hormone released, free corticosterone levels remained relatively lower in GDX+high than GDX+low testosterone replaced rats (Fig. 3). Basal free corticosterone concentrations did not vary as a function of testosterone replacement (free

Table 1 Mean ( \pm S.E.M.) plasma ACTH and $\beta$-END/ $\beta$-LPH concentration (pM) under basal and stress conditions in gonadectomized (GDX) rats replaced with either high $(\sim 5 \mathrm{ng} / \mathrm{ml}$;

T) or low ( $\sim 2 \mathrm{ng} / \mathrm{ml} ; \mathrm{t})$ testosterone replacement levels ( $n=13$ per group)

\begin{tabular}{|c|c|c|c|}
\hline & $\beta$-END/ $\beta$-LPH & АСТН & Ratio \\
\hline \multicolumn{4}{|l|}{ Basal } \\
\hline GDX + high $\mathrm{T}$ & $104 \cdot 8 \pm 14 \cdot 1$ & $22 \cdot 2 \pm 2 \cdot 7$ & $6 \cdot 3 \pm 2 \cdot 1$ \\
\hline GDX+low t & $128 \cdot 0 \pm 13 \cdot 7$ & $27 \cdot 8 \pm 1 \cdot 8$ & $4 \cdot 8 \pm 0 \cdot 5$ \\
\hline \multicolumn{4}{|l|}{ Stress peak ${ }^{1}$} \\
\hline GDX+high $T$ & $195 \cdot 6 \pm 15 \cdot 3$ & $127 \cdot 0 \pm 9 \cdot 8$ & $1 \cdot 6 \pm 0 \cdot 2$ \\
\hline GDX+low t & $322 \cdot 1 \pm 19 \cdot 3^{\star *}$ & $169 \cdot 9 \pm 8 \cdot 6^{* *}$ & $1 \cdot 9 \pm 0 \cdot 2$ \\
\hline \multicolumn{4}{|c|}{ Stress peak integral ${ }^{2}$} \\
\hline GDX+high $\mathrm{T}$ & $90 \cdot 7 \pm 10 \cdot 2$ & $104 \cdot 8 \pm 10 \cdot 1$ & $0 \cdot 97 \pm 0 \cdot 1$ \\
\hline GDX+low t & $194 \cdot 0 \pm 24 \cdot 2^{* *}$ & $142 \cdot 2 \pm 8 \cdot 7^{*}$ & $1 \cdot 42 \pm 0 \cdot 1^{*}$ \\
\hline
\end{tabular}

${ }^{1}$ Absolute plasma levels at termination of 10 min restraint; ${ }^{2}$ difference between basal and peak values;

${ }^{*} P<00 \cdot 01,{ }^{*} P<0 \cdot 05, \mathrm{GDX}+$ high T vs GDX+low $\mathrm{t}$. 

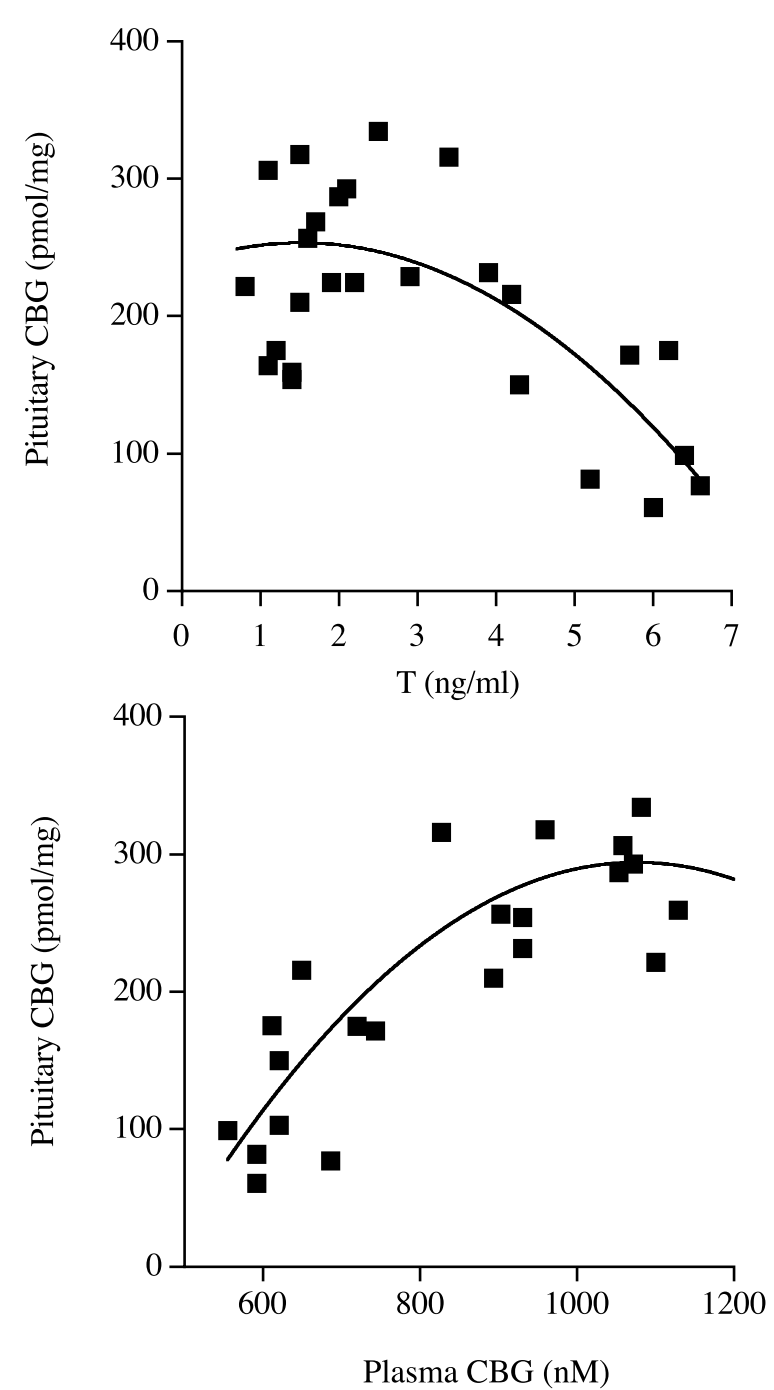

Figure 4 Intrapituitary CBG binding varies as a function of individual plasma testosterone (T) replacement levels (top) and as a function of individual plasma CBG levels (bottom) in GDX rats with subcutaneous implants of testosterone.

corticosterone $=3 \cdot 6 \pm 0.6 \mathrm{nM}$ and $3 \cdot 4 \pm 0.8 \mathrm{nM}$ in high and low testosterone-replaced rats respectively).

\section{Intrapituitary CBG (transcortin)}

Pituitary transcortin levels paralleled the effects of testosterone on plasma CBG (Fig. 4). Thus, transcortin binding was reduced in GDX rats replaced with higher testosterone levels. Regression analysis indicated a strong negative relationship $(r=0.66 ; \quad P=0 \cdot 0011)$ between transcortin binding and individual plasma testosterone concentrations (Fig. 4, top). Transcortin binding also varied strongly and positively as a function of plasma CBG (Fig. 4 bottom,

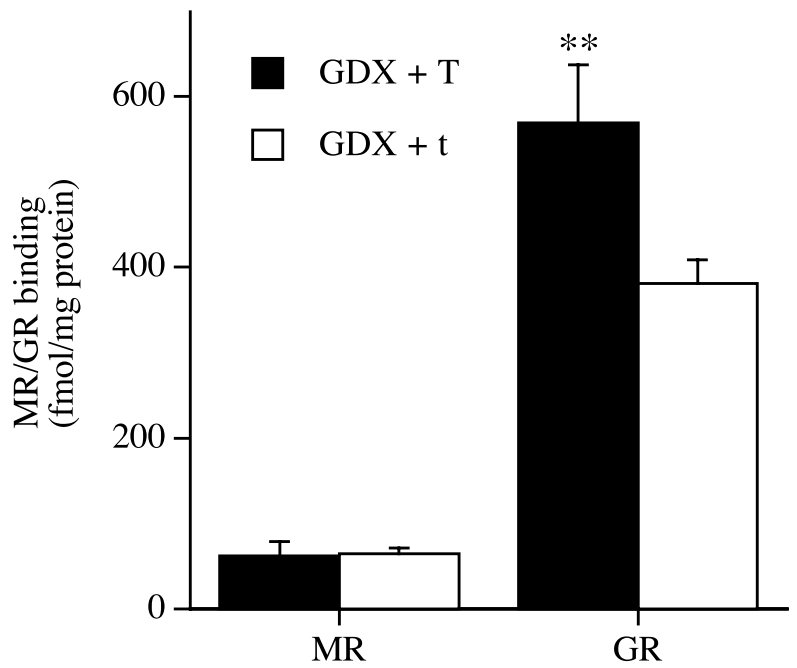

Figure 5 Mean ( \pm S.E.M.) hepatic mineralocorticoid (MR) and glucocorticoid (GR) receptor binding in GDX+high $\mathrm{T}$ and in GDX+low $t$ replaced rats $\left(n=7\right.$ per group). ${ }^{* *} P<0 \cdot 01$ compared with GDX rats with low testosterone replacement.

$r=0.80 ; P<0 \cdot 0001)$. In both cases, the relationships were best described using a 2 nd order polynomial fit.

\section{Corticosteroid receptor binding in liver}

Analysis of hepatic corticosteroid receptor levels as a function of testosterone replacement revealed no significant differences in mineralocorticoid receptor binding (Fig. 5). However, glucocorticoid receptor binding varied as a function of testosterone replacement. As a group, GDX rats replaced with higher plasma testosterone $(7 \cdot 6 \pm 0.7 \mathrm{ng} / \mathrm{ml})$ showed greater glucocorticoid receptor binding than GDX rats replaced with lower testosterone $(2 \cdot 5 \pm 0.5 \mathrm{ng} / \mathrm{ml})$ (Fig. 5).

\section{Anterior pituitary $\left.{ }^{3} \mathrm{H}\right]$ corticosterone nuclear uptake}

To examine how androgen-dependent differences in anterior pituitary transcortin binding could alter glucocorticoid uptake, pituitaries obtained from rats with high and low plasma testosterone levels were incubated in vitro with $\left[{ }^{3} \mathrm{H}\right]$ corticosterone concentrations approximating either basal $(10 \mathrm{nM})$ or stress $(100 \mathrm{nM})$ concentrations of free corticosterone. At $10 \mathrm{nM}$, there were no differences in $\left[{ }^{3} \mathrm{H}\right]$ corticosterone nuclear uptake (Fig. 6). However, at $100 \mathrm{nM}$, the nuclear uptake of $\left[{ }^{3} \mathrm{H}\right]$ corticosterone was significantly greater $(P<0 \cdot 01)$ in pituitaries from GDX rats with high plasma testosterone replacement than in GDX rats with low testosterone replacement (Fig. 6).

\section{Discussion}

The dose-related inhibitory effects of testosterone on corticotrope responses to stress may be linked to 


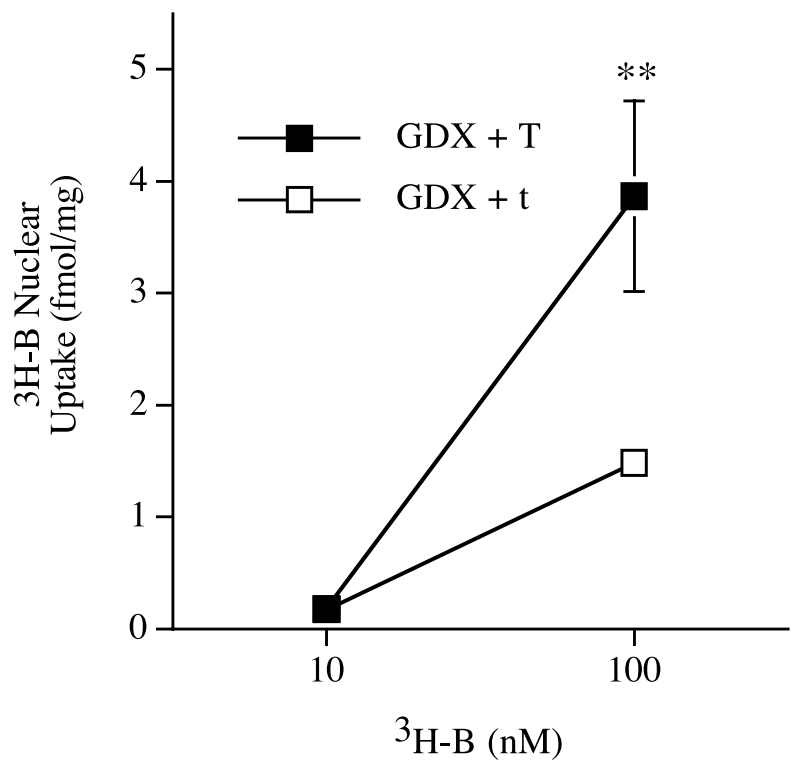

Figure 6 Specific nuclear uptake of $\left[{ }^{3} \mathrm{H}\right]$ corticosterone $\left({ }^{3} \mathrm{H}-\mathrm{B} ; 10\right.$ and $100 \mathrm{nM}$ ), in vitro, in anterior pituitaries from GDX+high $\mathrm{T}$ and from GDX+low t replaced rats ( $n=7$ per group). ${ }^{*} P<0 \cdot 01$ compared with GDX rats with low testosterone replacement.

decrements in plasma and intrapituitary CBG. Similar to our current findings, decreased intrapituitary CBG (or transcortin) has been associated with an increased nuclear uptake of corticosterone in vitro, and enhanced glucocorticoid inhibition of ACTH release in vivo (Sakly \& Koch 1981, 1983). In GDX rats receiving higher testosterone replacement levels, the nuclear uptake of $\left[{ }^{3} \mathrm{H}\right]$ corticosterone was elevated in pituitaries at a concentration of $100 \mathrm{nM}$, but not at $10 \mathrm{nM}$. This testosterone-dependent difference in the nuclear uptake of corticosterone is reflective of a functional change in the dynamics of transcortin and not corticosteroid receptor activity. Sex differences in corticosteroid receptor binding at the level of the anterior pituitary have not been reported (Ferrini et al. 1990, Burgess \& Handa, 1992). Further, mineralocorticoid and glucocorticoid receptor binding in the anterior pituitary do not vary as a function of androgen replacement in gonadectomized rats replaced with DHT or testosterone (Handa et al. 1994, Viau \& Meaney 1996). The fact that the nuclear uptake of corticosterone was distinguished with $100 \mathrm{nM}$ but not with $10 \mathrm{nM}$ corticosterone is, on the one hand, consistent with the relatively lower affinity of transcortin for corticosterone compared with corticosteroid receptors $(10 \mathrm{nM}$ vs 0.5-2.5 nM respectively). On the other hand, changes in transcortin binding may only be relevant to periods of increased HPA drive either during the circadian peak in basal HPA activity or during stress when free corticosterone concentrations approximate or exceed $100 \mathrm{nM}$.
In addition to ACTH, GDX rats with higher testosterone replacement levels displayed reduced $\beta$-END $/ \beta-\mathrm{LPH}$ responses to restraint, indicating similar inhibitory influences of testosterone on the stimulated release of proopiomelanocortin (POMC)-related peptides. Chromatographic analyses using antisera identical to our own indicate that while $\beta$-END derived from intermediate lobe melanotropes represents the principal source of circulating endorphins under basal conditions, $\beta$-LPH release from the anterior pituitary dominates over $\beta$-END in response to acute stress (De Souza \& Van Loon, 1985, Van Loon \& De Souza 1987). Given the shift in the ratio of $\beta-E N D / \beta-\mathrm{LPH}: \mathrm{ACTH}$ secreted during restraint as a function of testosterone replacement, reduced in rats with higher testosterone replacement, it is tempting to speculate a role for testosterone (and transcortin) in regulating $\mathrm{POMC}$ processing in response to acute stress. However, because the relative contributions of $\beta$-END and $\beta-\mathrm{LPH}$ were not determined in the present study, the extent to which the findings speak of changes in POMC processing or the source of endorphins secreted remains unresolved. Notwithstanding this limitation, what merits some attention are previous studies identifying even greater disparities between $\beta-\mathrm{LPH}$ and ACTH secretion under more chronic stress conditions. Repeated restraint potentiates $\beta-\mathrm{LPH}$ release, without affecting the magnitude of the $\beta$-END and ACTH responses (De Souza \& Van Loon 1985, Van Loon \& De Souza 1987). Interestingly, this potentiating effect on $\beta-\mathrm{LPH}$ is eliminated by adrenalectomy (ADX), indicating that the inhibition of $\beta-\mathrm{LPH}$ processing may be glucocorticoid dependent (see De Souza \& Van Loon 1989). Since testosterone secretion varies in response to repeated stress, testosterone-dependent alterations in pituitary $\mathrm{CBG}$ and corticosterone uptake may play a greater role in POMC processing under more chronic or repeated stress conditions.

In anterior pituitary cells, CBG is found in membrane fractions in addition to the cytosol compartment (Koch et al. 1978). Membrane-bound and cytosolic CBG (transcortin) levels in the pituitary have both been shown to parallel the changes in circulating CBG concentrations (Koch et al. 1978, Tannebaum et al. 1997). Interestingly, binding of corticosterone to hypothalamic membrane fractions is absent in perfused mice (Orchinik et al. 1991). Thus, membrane-bound CBG may possibly reflect the transit of the globulin through the membrane as it diffuses into the cell. Our data also indicate a parallel relationship between pituitary transcortin and plasma CBG concentrations. However, transcortin binding failed to increase beyond plasma CBG levels of $1000 \mathrm{nM}$ (see Fig. 4, bottom panel). This would suggest that CBG diffusion across cell membranes is a saturable process. Considering the dual inhibitory effects of testosterone on plasma CBG and transcortin, it is likely that membranebound CBG receptor levels are also affected. Given the 
proposed role for membrane-bound CBG in mediating rapid glucocorticoid effects on cellular activity (see Orchinik et al. 1991), it is attractive to speculate that testosterone may also modulate the nontranscriptional actions of corticosterone.

Plasma CBG shows a diurnal rhythm in circulating levels, rising in the p.m. and declining during the a.m. period in the rat (Hsu \& Kuhn 1988, Meaney et al. 1992). This rhythm, however, is not re-instated in ADX rats provided with corticosterone in their drinking water, a replacement regimen which mimics the diurnal corticosterone rhythm (Hsu \& Kuhn 1988). Thus, circulating glucocorticoids appear to regulate the range, but not the diurnal rhythm in plasma CBG. It is important to note that ADX also causes a decrease in plasma testosterone levels (Viau et al. 1999). Moreover, testosterone secretion in males cycles in a manner which reciprocates the daily rhythm of CBG and corticosterone release (Kalra \& Kalra 1977, Plymate et al. 1989, Winters et al. 1991). Finally, the diurnal rhythm in cortisol levels is abolished by GDX in male primates (Smith \& Norman 1987). Taken together, these findings suggest that the diurnal pattern in CBG synthesis and release is multifactorial and, at the very least, sensitive to corticosterone and testosterone interactions. Since hepatic production of CBG is inhibited by glucocorticoids directly (Dallman et al. 1987, Levin et al. 1987), a critical point of this adrenal-gonadal interaction on CBG appears to reside at the level of the hepatic glucocorticoid receptor. This is indicated by the positive effect of increasing testosterone replacement levels on glucocorticoid receptor binding in the liver, suggesting that glucocorticoid suppression of CBG synthesis may be enhanced by testosterone.

The dose-related effects of testosterone on hepatic glucocorticoid receptors and presumably on CBG synthesis and release should not be underestimated, revealing additional mechanisms by which the adrenal and gonadal systems interact (reviewed by Viau 2002). In keeping with this interactive nature, we have previously shown that corticosterone inhibition of acute stressinduced ACTH release is reduced by gonadectomy and restored with testosterone replacement (Viau et al. 1999), and that this likely involves testosterone- and corticosterone-dependent changes in paraventricular nucleus (Viau et al. 2001, 2003). Since changes in CBG synthesis and capacity can effectively alter glucocorticoid receptor occupancy in the brain and, as shown here, in the pituitary, corticotrope responses to acute stress may reflect a balance between effects on secretagogue release centrally and corticotrope responses peripherally. As acute stress exposure produces long-term changes in both plasma and pituitary CBG (Tannenbaum et al. 1997), plasma testosterone levels at the time of acute stress could have enduring effects on how the HPA axis responds to subsequent stress exposure (see van Dijken et al. 1993).

\section{Acknowledgements}

V V holds a New Investigator award from the Canadian Institutes for Health Research and a Scholar award from the Michael Smith Foundation for Health Research.

\section{Funding}

This research was supported by Canadian Institutes of Health Research Grant.

\section{References}

Bradford MM 1976 A rapid and sensitive method for quantitation of microgram quantities of protein utilizing the principle of protein-dye binding. Analytical Biochemistry 72 248-254.

Burgess LH \& Handa RJ 1992 Chronic estrogen-induced alterations in adrenocorticotropin and corticosterone secretion, and glucocorticoid receptor-mediated functions in female rats. Endocrinology 131 1261-1269.

Coirini H, Magarinos AM, De Nicola AF, Rainbow TC \& McEwen BS 1985 Further studies of brain aldosterone binding sites employing new mineralocorticoid and glucocorticoid receptor markers in vitro. Brain Research 361 212-216.

Dallman MF, Akana SF, Cascio CS, Darlington DN, Jacobson L \& Levin N 1987 Regulation of ACTH secretion: variations on a theme of B. Recent Progress in Hormone Research 43 113-173.

De Souza EB \& Van Loon GR 1985 Differential plasma $\beta$-endorphin, $\beta$-lipotropin, and adrenocorticotropin responses to stress in rats. Endocrinology 116 1577-1586.

De Souza EB \& Van Loon GR 1989 Rate sensitive glucocorticoid feedback inhibition of adrenocorticotropin and $\beta$-endorphin/ $\beta$-lipotropin secretion in rats. Endocrinology 125 2927-2934.

van Dijken HH, de Goeij DC, Sutanto W, Mos J, de Kloet ER \& Tilders FJ 1993 Short inescapable stress produces long-lasting changes in the brain-pituitary-adrenal axis of adult male rats. Neuroendocrinology 58 57-64.

Ferrini M, Margarinos AM \& De Nicola AF 1990 Oestrogens down-regulate type I but not type II adrenal corticoid receptors in rat anterior pituitary. Journal of Steroid Biochemistry 35 671-677.

Gala RR \& Westphal U 1965 Corticosteroid-binding globulin in the rat: studies on the sex difference. Endocrinology 77 841-851.

Handa RJ, Nunley KM, Lorens SA, Louie JP, McGivern RF \& Bollnow MR 1994 Androgen regulation of adrenocorticotropin and corticosterone secretion in the male rat following novelty and footshock stressors. Physiology and Behavior 55 117-124.

Henning S 1978 Plasma concentrations of total and free corticosterone during development in the rat. American Journal of Physiology 235 E451-E456.

Hsu B R-S \& Kuhn RW 1988 The role of the adrenal in generating the diurnal variation in circulating levels of corticosteroid-binding globulin in the rat. Endocrinology 122 421-426.

Iny LJ, Gianoulakis C, Palmour RM \& Meaney MJ 1987 The $\beta$-endorphin response to stress during postnatal development in the rat. Developmental Brain Research 31 177-181.

Jacobson L \& Sapolsky R 1991 The role of the hippocampus in feedback regulation of the hypothalamic-pituitary-adrenal axis. Endocrine Reviews 12 118-133.

Kalra PS \& Kalra SP 1997 Circadian periodicities of serum androgens, progesterone, gonadotropins and luteinizing hormone-releasing hormone in male rats: the effects of hypothalamic deafferentation, castration and adrenalectomy. Endocrinology 101 1821-1827. 
Keller N, Sendelbeck LR, Richardson UI, Moore C \& Yates FE 1966 Protein binding of corticosteroids in undiluted rat plasma. Endocrinology 79 884-906.

de Kloet ER \& McEwen BS A putative glucocorticoid receptor and a transcortin-like macromolecule in pituitary cytosol. Biochimica et Biophysica Acta 421 115-123.

Koch B, Bucher B \& Mialhe C 1974 Pituitary nuclear retention of dexamethasone and ACTH biosynthesis. Neuroendocrinology 15 365-375.

Koch B, Lutz B, Briaud B \& Mialhe C 1976 Heterogeneity of pituitary glucocorticoid binding: evidence for a transcortin-like compound. Biochimica et Biophysica Acta 44 497-507.

Koch B, Lutz-Bucher B, Briaud B \& Mialhe C 1978 Specific interaction of corticosteroids with binding sites in the plasma membranes of the rat anterior pituitary gland. Journal of Endocrinology 79 215-222.

Kurabekova RM, Mataradze GD \& Rozen VB 1988 Mechanisms of sex differentiation of the level of corticosteroid-binding globulin in rats. Problema Endokrinology 34 66-70.

Le Mevel JC, Abitibol S, Beraud G \& Maniey J 1978 Dynamic changes in plasma adrenocorticotrophin after neurotrophic stress in male and female rats. Journal of Endocrinology 76 359-360.

Levin N, Akana SF, Jacobson L, Kuhn RW, Siiteri PK \& Dallman MF 1987 Plasma adrenocorticotropin is more sensitive than transcortin production or thymus weight to inhibition by corticosterone in rats. Endocrinology 121 1104-1112.

McCormick CM, Linkroum W, Sallinen BJ \& Miller NW 2002 Peripheral and central sex steroids have differential effects on the HPA axis of male and female rats. Stress 5 235-247.

Martin CE, Cake MH, Hartmann PE \& Cook IF 1977 Relationship between foetal corticosteroids, maternal progesterone and parturition in the rat. Acta Endocrinologica 84 167-176.

Meaney MJ, Aitken DH, Bodnoff SR, Iny LJ \& Sapolsky RM 1985 The effects of postnatal handling on the development of the glucocorticoid receptor systems and stress recovery in the rat. Progress in Neuro-Psychopharmacoogy and Biological Psychiatry 9 731-734.

Meaney MJ, Aitken DH, Sharma S \& Viau V 1992 Basal ACTH, corticosterone, and corticosterone-binding globulin levels over the diurnal cycle, and hippocampal type I and type II corticosteroid receptors in young and old, handled and non-handled rats. Neuroendocrinology 55 204-213.

Orchinik M, Murray TF \& Moore FL 1991 A corticosteroid receptor in neuronal membranes. Science 252 1848-1851.

Pardridge WM 1981 Transport of protein-bound hormones into tissues in vivo. Endocrine Reviews 2 103-114.

Perrot-Applanat M, Racadot O \& Milgrom E 1984 Specific localization of plasma corticosteroid-binding globulin immunoreactivity in pituitary corticotrophs. Endocrinology 115 559-569.

Plymate SR, Vaughan GM, Mason AD \& Pruitt BA 1987 Central hypogonadism in burned men. Hormone Research 27 152-158.

Plymate SR, Tenover JS \& Bremmer WJ 1989 Circadian variation in testosterone, sex hormone-binding globulin bound testosterone in healthy young and elderly men. Journal of Andrology 10 366-371.

Reul JMHM \& de Kloet ER 1985 Two receptor systems for corticosterone in rat brain: microdistribution and differential occupation. Endocrinology 117 2505-2510.

Sakly M \& Koch B 1981 Ontogenesis of glucocorticoid receptors in anterior pituitary gland: transient dissociation among cytoplasmic receptor density, nuclear uptake, and regulation of corticotropic activity. Endocrinology 108 591-596.

Sakly M \& Koch B 1983 Ontogenetical variations of transcortin modulate glucocorticoid receptor function and corticotropic activity in the pituitary gland. Hormone and Metabolic Research 15 92-96.

Siiteri PK, Murai JT, Hammond GL, Nisker JA, Raymoure WJ \& Kuhn RW 1982 The serum transport of steroid hormones. Recent Progress in Hormone Research 38 457-491.
Smith CJ \& Norman RL 1987 Circadian periodicity in circulating cortisol is absent after orchidectomy in rhesus macaques. Endocrinology 121 2186-2191.

Smith ER, Damassa DA \& Davidson JM 1977 Hormone administration: peripheral and intracranial implants. Methods in Psychobiology 3 249-279.

Tallarida RJ \& Murray RB 1981 Area under a curve: Simpson's rule and trapezoidal rule. In Manual of Pharmacological Calculations with Computer Programs, pp 47-49. New York: Springer.

Tannenbaum B, Rowe W, Sharma S, Diorio J, Steverman A, Walker M \& Meaney MJ 1997 Dynamic variations in plasma corticosteroid-binding globulin and basal HPA activity following acute stress in adult rats. Journal of Neuroendocrinology 9 163-168.

Van Loon GR \& De Souza EB 1987 Regulation of stress-induced secretion of POMC-derived peptides. In The HypothalamicPituitary-Adrenal Axis Revisited. Eds WF Ganong, MF Dallman \& JL Roberts. Annals of the New York Academy of Sciences $\mathbf{5 1 2}$ 300-307.

Viau V 2002 Functional cross-talk between the hypothalamic-pituitary-gonadal and -adrenal axes. Journal of Neuroendocrinology 14 506-513.

Viau V \& Meaney MJ 1996 The inhibitory effect of testosterone on hypothalamic-pituitary-adrenal responses to stress is mediated by the medial preoptic area. Journal of Neuroscience 16 1866-1876.

Viau V, Sharma S, Plotsky PM \& Meaney MJ 1993 Increased plasma ACTH responses to stress in nonhandled compared with handled rats require basal levels of corticosterone and are associated with increased levels of ACTH secretagogues in the median eminence. Journal of Neuroscience 13 1097-1105.

Viau V, Sharma, S \& Meaney MJ 1996 Changes in plasma adrenocorticotropin, corticosterone, corticosteroid-binding globulin, and hippocampal glucocorticoid receptor occupancy/translocation in rat pups in response to stress. Journal of Neuroendocrinology 8 1-8.

Viau V, Chu A, Soriano L \& Dallman MF 1999 Independent and overlapping effects of corticosterone and testosterone on corticotropin-releasing hormone and arginine vasopressin mRNA expression in the paraventricular nucleus of the hypothalamus and stress-induced adrenocorticotropic hormone release. Journal of Neuroscience 19 6684-6693.

Viau V, Soriano L \& Dallman MF 2001 Androgens alter corticotropin releasing hormone and arginine vasopressin mRNA within forebrain sites known to regulate activity in the hypothalamic-pituitaryadrenal axis. Journal of Neuroendocrinology 13 442-452.

Viau V, Lee P, Sampson J \& Wu J 2003 A testicular influence on restraint-induced activation of medial parvocellular neurons in the paraventricular nucleus in the male rat. Endocrinology 144 3067-3075

Walker CD, Sapolsky RM, Meaney MJ, Vale WW \& Rivier C 1986 Increased pituitary sensitivity to glucocorticoid feedback during the stress non-responsive period in the rat. Endocrinology 119 1816-1821.

Walker CD, Akana SF, Cascio CS \& Dallman MF 1990 Adrenalectomy in the neonate: adult-like adrenocortical system responses to both removal and replacement of corticosterone. Endocrinology 127 832-842.

Winters SJ, Medhamurthy R, Gay VL \& Plant TM 1991 A comparison of moment to moment and diurnal changes in circulating inhibin and testosterone concentrations in male rhesus monkeys. Endocrinology 129 1755-1761.

Received 7 January 2004

Accepted 16 January 2004

Made available online as an

Accepted Preprint 22 January 2004 